\title{
O DIREITO SOCIAL AO TRABALHO E O PRINCÍPIO DA ISONOMIA TRIBUTÁRIA FACE A ISENÇÃO DE IMPOSTO SOBRE A RENDA NA REMUNERAÇÃO DOS PROFESSORES
}

\author{
Consuelo Yatsuda Moromizato Yoshida ${ }^{1}$ \\ Milena Zampieri Sellmann ${ }^{2}$
}

\section{RESUMO}

$\mathrm{O}$ art. $6^{\circ}$ da $\mathrm{CF} / 88$ prevê o trabalho como direito social, assim os direitos dos trabalhadores, bem como a valoração e proteção do trabalho devem ser objeto de medidas afirmativas. O Imposto sobre a Renda incide sobre acréscimos patrimoniais. Alguns rendimentos de pessoas físicas não se sujeitam, por disposição legal, a incidência do imposto federal e há projetos de leis objetivando incluir dentre as isenções a remuneração auferida pelos professores. Todavia, tais projetos são inconstitucionais por violação à isonomia tributária que veda a distinção entre contribuintes em razão da ocupação profissional ou função por eles exercida.

Palavras-chave: Isenção de IR. Direito social ao trabalho. Princípio da isonomia tributária.

\section{THE SOCIAL RIGHT TO WORK AND THE TAX ISONOMY PRINCIPLE IN VIEW OF THE EXEMPTION ON INCOME TAX OF TEACHERS REMUNERATION.}

\begin{abstract}
The art. 6 of the CF / 88 prescribes work as a social right, there for the workers' rights, as well as valuation and protection of work must be subject to affirmative measures. The Income Tax is levied on capital increases. Some income of individuals is not subject, by legal provision, to the incidence of federal tax and there are draft laws aimed at including among the exemptions the remuneration earned byteachers. However, such projects are unconstitutional for violation of the tax isonomy that forbids the distinction between taxpayers due to the occupation or function performed by them.
\end{abstract}

Keywords: Income tax exemption. Social right to work. Tax isonomy principle.

\section{INTRODUÇÃO}

Os Direitos Sociais são considerados de segunda dimensão ou geração e concretizam-se por meio de políticas públicas que objetivem garantir o acesso à

\footnotetext{
${ }^{1}$ Doutora e Mestre em Direito pela PUC/SP. Professora Assistente do Departamento de Direitos Humanos, Difusos e Coletivos da PUC/SP. Professora de Direito Ambiental na graduação e na pósGraduação (mestrado e doutorado) e Coordenadora dos Cursos de Especialização em Direito Ambiental e Gestão Estratégica da Sustentabilidade (PUC/COGEAE/SP). Professora do Programa de Mestrado do Centro Universitário Salesiano de São Paulo/U.E. de Lorena. Desembargadora Federal cyoshida@trf3.jus.br

${ }^{2}$ Doutora, Mestre e Especialista em Direito pela PUC-SP. Professora nos cursos de graduação e pósgraduação (especialização e mestrado) do Centro Universitário Salesiano de São Paulo/U.E. de Lorena. Professora do Damásio Educacional e da Faculdade de Direito Damásio de Jesus. Advogada milenasellmann@hotmail.com
} 
educação, a saúde, a alimentação, ao trabalho, a moradia, o transporte, o lazer, a segurança, a previdência social, proteção à maternidade e à infância, a assistência aos desamparados, direitos previstos no artigo $6^{\circ}$ da Constituição da República Federativa do Brasil.

Especialmente no que tange ao direito social ao trabalho, a Constituição Federal, em vários dispositivos, preconiza a proteção e valorização ao trabalho, bem como aos direitos inerentes aos trabalhadores, de forma que, é imprescindível a tomada de medidas positivas por parte do Poder Público focadas na proteção de todos os direitos inerentes não só ao trabalhador, como também ao seu direto ao trabalho.

O artigo 153, inciso III, da Constituição Federal, atribui competência a União para instituição do Imposto sobre a Renda, o qual incide sobre acréscimos patrimoniais, assim considerado o saldo positivo resultante do confronto entre certas entradas e certas saídas, ocorridas ao longo de um dado período.

Comina também o texto constitucional que o imposto federal deverá ser pautado pelos critérios da generalidade, universalidade e progressividade.

A isenção é causa de exclusão do crédito tributário e consiste na dispensa, por lei do ente federado competente, da obrigação de pagar um tributo. Desta feita, lei federal poderá conceder isenção de Imposto sobre a Renda. É o que ocorre com o artigo $6^{\circ}$ da Lei $\mathrm{n}^{\circ} 7.713 / 1988$ (alterada por leis posteriores), cujos incisos elenca as hipóteses de isenção do imposto sobre os rendimentos percebidos por pessoas físicas.

Projetos de leis tramitam no Congresso Nacional objetivando incluir, dentre as situações abarcadas pela isenção do Imposto sobre a Renda, os rendimentos auferidos por uma categoria profissional específica, qual seja, a dos professores.

Todavia, tais projetos gozam de inconstitucionalidade por violação ao Princípio da Isonomia Tributária que comina ser vedado tratamento diferenciado entre contribuintes que se encontrem em situação equivalente e proíbe distinção em razão da ocupação profissional ou função por eles exercida.

A concessão de isenção de Imposto sobre a Renda nos rendimentos auferidos pelos professores ferirá também o critério constitucional da generalidade que impõe a tributação de todas as pessoas via imposto federal. É o que será demonstrado no presente trabalho.

\section{Direitos sociais como direito fundamental.}


A Constituição de 1988 preocupou-se em albergar direitos e garantias fundamentais, a fim de garantir o mínimo de dignidade à pessoa humana, à inviolabilidade de domicilio, à liberdade de associação (direitos individuais, conhecidos como de primeira geração), bem como definir deveres do Estado para a concretização do mínimo existencial para que o Brasil fosse um Estado social (direitos fundamentais sociais, conhecidos como de segunda geração).

Marcelo Novelino explica que "a expressão direitos fundamentais surgiu na França, em 1770, no movimento político e cultural que deu origem à Declaração Universal dos Direitos do Homem e do Cidadão, de 1789”. (2012, p. 395)

Os Direitos e Garantias Fundamentais estão previstos na Constituição Federal de 1988, no Título II, estando divididos em: direitos e deveres individuais e coletivos, direitos sociais, direitos de nacionalidade, direitos políticos e partidos políticos.

Pedro Lenza ensina que:

\begin{abstract}
Nos termos do artigo $5^{\circ}, \S^{\circ}$, as normas definidoras dos direitos e garantias fundamentais têm aplicação imediata. Trata-se, portanto, de regra que naturalmente comporta exceções trazidas pelo constituinte originário [...]. $(2010$, p.743)
\end{abstract}

A Doutrina, a fim de organizar os estudos a respeitos do Direitos e Garantias Fundamentais, costuma dividi-los em quatro dimensões ou gerações.

Os direitos de primeira dimensão são classificados como direitos individuais ou liberdades públicas como a vida, liberdade, propriedade etc. Já os de segunda dimensão são os direitos sociais como saúde, educação, trabalho e assistência aos desamparados. Tem-se também os de terceira dimensão, os quais estão compreendidos aqueles voltados para a proteção de toda a humanidade e não exclusivamente de determinado indivíduo ou grupo, tais como direito ao desenvolvimento, o direito à paz e o direito ao meio ambiente equilibrado (NUNES JUNIOR, 2017, p. 748-751). Os direitos à democracia, informação e pluralismo são classificados como de quarta dimensão.

Como exposto, os Direitos Sociais são considerados de segunda dimensão e, concretizam-se por meio de políticas públicas para garantir o acesso à educação, à saúde, ao trabalho e ao lazer.

O artigo $6^{\circ}$ da Constituição da República Federativa do Brasil preconiza que são direitos sociais a educação, a saúde, a alimentação, o trabalho, a moradia, o transporte, o 
lazer, a segurança, a previdência social, a proteção à maternidade e à infância, a assistência aos desamparados.

Ensina Luís Alberto David Araújo (2010, p. 218):

\begin{abstract}
[...] que os direitos sociais, como os direitos fundamentais de segunda geração, são aqueles que reclamam do Estado um papel prestacional, de minorização das desigualdades sociais. Nesse sentido, o art. $6^{\circ}$ do texto constitucional, embora ainda de forma genérica, faz alusão expressa aos direitos sociais: a educação, a saúde, o trabalho, a moradia, o lazer, a segurança, a previdência social, a proteção a maternidade e à infância, a assistência aos desamparados. Ressalta-se que o direito à moradia foi acrescido pela Emenda Constitucional n. 26, de 14 de fevereiro de 2000, colocando-a como direito social explicito.
\end{abstract}

Segundo Inocêncio Mártires Coelho (2009, p. 759) os direitos sociais "são concebidos como instrumentos destinados à efetiva redução e/ou supressão de desigualdades, segundo a regra de que se deve tratar igualmente os iguais e desigualmente os desiguais, na medida de sua desigualdade".

Já para Alexandre de Moraes (2002, p. 202):

Direitos Sociais são direitos fundamentais do homem, caracterizando-se como verdadeiras liberdades positivas, de observância obrigatória em um Estado Social de Direito, tendo por finalidade a melhoria das condições de vida aos hipossuficientes, visando à concretização da igualdade social, e são consagrados como fundamentos do Estado democrático, pelo art. $1^{\circ}$, IV, da Constituição Federal.

Os Direitos Sociais, tais como consagrados pela Carta Constitucional são importantes fontes para a concretização do princípio da igualdade material e, por consequência, ao princípio da igualdade formal, também consagrado na Carta Magna.

De acordo com art. $5^{\circ}$, caput da Constituição de 1988:

Todos são iguais perante a lei, sem distinção de qualquer natureza, garantindo-se aos brasileiros e aos estrangeiros residentes no País a inviolabilidade do direito à vida, à liberdade, à igualdade, à segurança e à propriedade $[\ldots]$

A igualdade formal, consubstanciada no citado dispositivo, no sentido de que “todos são iguais perante a lei” só será efetivamente alcançada se também atendido o respeito à igualdade material (tratar os desiguais na medida de sua desigualdade, a fim de lhes assegurar condições igualitárias.

Sobre o assunto, mister destacar as palavras de José Afonso da Silva, relacionando os direitos sociais, tal como a educação, como atendimento ao princípio da igualdade: 
O princípio da igualdade insculpido no artigo $5^{\circ}$ da Constituição Federal deve permear a interpretação e concretização de todos os direitos fundamentais sociais, dentre eles, o direito à educação. Por ser um direito social, tende a realizar a equalização de situações sociais desiguais, ligando-se, assim, ao direito à igualdade material, o que, por sua vez proporciona condição mais compatível com o exercício efetivo da liberdade (2010, p. 285 e 286).

Por isso, os Direitos Sociais devem ser vistos como mola propulsora do real atendimento ao princípio da igualdade e são deveres do Estado que trarão o mínimo de condições dignas de sobrevivência o que trará, por consequência, atendimento ao fundamento constitucional da República à dignidade da pessoa humana.

Neste sentido, vislumbra-se dentre os direitos sociais elencados no rol do art. $6^{\circ}$ o direito ao trabalho, o qual deve ser visto, não só como como expressão do direito de liberdade, mas especialmente como meio de minimização das desigualdades, finalidade precípua dum estado social.

\subsection{O direito social ao trabalho.}

A Constituição Federal de 1988, em seu texto, traz pelo menos cinco fragmentos que tratam da proteção ao emprego e aos direitos dos trabalhadores.

$\mathrm{O}$ primeiro, previsto no art. $1^{\circ}$, inciso IV, elenca, dentre os fundamentos da República Federativa do Brasil, os valores sociais do trabalho. O segundo está no art. $6^{\circ}$ que especifica que o direito ao trabalho é um direito social. O terceiro vem disposto nos incisos do art. $7^{\circ}$, especialmente, nos I, II, XXX e XXXI, os quais protegem o trabalhador da dispensa arbitrária ou sem justa causa, mesmo que diante de indenização, resguardam o seguro desemprego, em caso de desemprego voluntário, proíbem diferença de salários, de exercício de funções e de critérios de admissão por motivo de sexo, idade, cor ou estado civil e, por fim, vedam discriminação quanto ao salário e critérios de admissão do trabalhador portador de deficiência.

O quarto está expresso no art. 170 da Carta Magna, cujo caput comina que a ordem econômica será fundada na valorização do trabalho humano e o inciso VII inclui a busca do pleno emprego como um dos seus princípios. O quinto, disposto no art. 193, impõe que a Ordem Social tenha por base o primado do trabalho.

Fato é que, o direito ao trabalho constitui umas das principais formas de realização da dignidade da pessoa humana. Exatamente por isso, é que Mauricio 
Godinho Delgado defende que o texto constitucional reconhece o direito social ao trabalho "como condição da efetividade da existência digna" (2005. p. 1.114).

Corrobora José Felipe Ledur (1998, p. 98):

[...] a realização do direito ao trabalho fará com que a dignidade humana assuma nítido conteúdo social, na medida em que a criação de melhores condições de vida resultar benéfica não somente para o indivíduo em seu âmbito particular, mas para o conjunto da sociedade.

Em sendo assim, é preciso a tomada de medidas positivas por parte do Poder Público focadas na proteção de todos os direitos inerentes não só ao trabalhador, como também ao seu direto ao trabalho.

Eros Roberto Grau explica:

No quadro da Constituição de 1988, de toda sorte, da interação entre esses dois princípios e os demais por ela contemplados - particularmente o que define como fim da ordem econômica (mundo do ser) assegurar a todos existência digna - resulta que valorizar o trabalho humano e tomar como fundamento o valor social do trabalho importa em conferir ao trabalho e seus agentes (os trabalhadores) tratamento peculiar. (2014, p. 196)

Acrescenta o autor:

Esse tratamento, em uma sociedade capitalista moderna, peculiariza-se na medida em que o trabalho passa a receber proteção não meramente filantrópica, porém politicamente racional. Titulares de capital e de trabalho são movidos por interesses distintos, ainda que se o negue ou se pretenda enunciá-los como convergentes. Daí por que o capitalismo moderno, renovado, pretende a conciliação e composição entre ambos. Esta pretensão é instrumentalizada através do exercício, pelo Estado - pelo Estado, note-se-, de uma série de funções que, [...]. A evolução do Estado gendarme, garantidor da paz, até o Estado do bem estar keinesiano, capaz de administrar e distribuir os recursos da sociedade "de forma a contribuir para a realização e a garantia das nações prevalentes de justiça, [...] (2014, p. 196)

Em suma, para que se tenha a concretização da dignidade da pessoa humana, faz-se necessário a valoração e proteção do trabalho, seja como direito fundamental, seja como direito social, bem como a tomada de medidas públicas objetivando garantir o direito social ao trabalho.

\section{Imposto sobre a renda (IR) e seus critérios informadores.}

Dentre os impostos de competência da União está o Imposto sobre a Renda e Proventos de Qualquer Natureza, previsto no artigo 153, inciso III, da Constituição Federal. 
Constitui o conteúdo semântico mínimo da expressão "renda e proventos de qualquer natureza" o saldo positivo resultante do confronto entre certas entradas e certas saídas, ocorridas ao longo de um dado período.

Saldo positivo no sentido de plus, de acréscimo patrimonial, de incremento ou de riqueza nova. Para se chegar a este plus, exige-se o confronto entre certas entradas no patrimônio do contribuinte e certas saídas, consideradas como elementos que deverão ser subtraídos dos ingressos. "Certas" entradas, posto que, o imposto incide somente as modificações patrimoniais consistentes em acréscimos, e não sobre as mutações decorrentes de meros ingressos, bem como não incide sobre elementos já integrantes do patrimônio. "Certas" saídas, já que nem todas são aptas a neutralizar os ingressos.

Esclarece José Artur Lima Gonçalves (2002, p. 180):

A idéia de saldo positivo traduz a noção de plus, de extra, de algo a mais, de acréscimo. [...] Renda haverá, portanto, quando houver sido detectado um acréscimo, um plus, tenha ele, ou não, sido consumido; seja ele ou não, representado por instrumentos monetários, diretos, ou por bens, imateriais ou físicos, móveis ou imóveis, agora não importa.

E completa:

Para que haja renda, deve haver acréscimo patrimonial - aqui entendido como incremento (material ou imaterial, representado por qualquer espécie de direitos ou bens, de qualquer natureza - o que importa é o valor em moeda do objeto desses direitos) - ao conjunto líquido de direitos de um dado sujeito

Da interpretação das normas constitucionais dessume-se que a Constituição Federal estabeleceu período para apuração do saldo positivo correspondente a um exercício financeiro, lapso compreendido entre $1^{\circ}$ de janeiro a 31 de dezembro de um determinado ano.

Por sua vez, o Código Tributário Nacional - Lei n. 5.172/66, diploma que encerra normas gerais de direito tributário, dispôs sobre o imposto em comento em três artigos, quais sejam, os artigos 43,44 e 45 .

São tributados pelo imposto federal os acréscimos patrimoniais ou elementos patrimoniais novos, gerados pelo patrimônio ou pelo próprio contribuinte, a título oneroso.

$\mathrm{O}$ art. $153, \S 2^{\circ}$, inciso I, impõe que o Imposto sobre a Renda seja informado pelos critérios da generalidade, da universalidade e da progressividade. 
A característica da generalidade impõe que o imposto federal alcance todas as pessoas que realizarem o fato gerador, isto é, todo aquele que auferir "renda e proventos de qualquer natureza".

Mary Elbe de Queiroz (2004, p. 37) explica o sentido do critério da generalidade:

\footnotetext{
Significa que todas as pessoas, independentemente de qualquer condição, cor, ração, credo, sexo, estado civil, que realizem fatos em concreto, previstos em abstrato na hipótese da lei, submetem-se à incidência do imposto, exceto quando alcançadas por imunidade e nos casos legalmente previstos.
}

Assim, decorre do cumprimento ao critério a vedação do estabelecimento de privilégios e discriminações entre contribuintes, já que a determinação constitucional tem por escopo evitar desigualdades, impedindo discriminações tributárias face as características pessoais do contribuinte ou de suas condições.

Por sua vez, o critério da universalidade exige que a tributação por via do imposto sobre a renda recaia sobre a totalidade das "rendas e proventos" auferidos, sem qualquer distinção de espécie, denominação, localização, condição jurídica, nacionalidade da fonte.

Ao estatuir a Constituição Federal que a tributação deve ser universal, veda a tributação fragmentada dos acréscimos patrimoniais auferidos. Impõe que o gravame incidia sobre todos os rendimentos sofridos, com o mesmo tratamento fiscal e sem a possibilidade de separação da espécie da renda obtida.

Todavia, o critério da universalidade não se confunde com o critério da generalidade. Isto porque aquele impõe considerar a "renda e os proventos de qualquer natureza" em sua totalidade, dizendo respeito ao patrimônio do contribuinte, isto é, ao acréscimo de elemento patrimonial novo. Já a generalidade se refere às pessoas, e determina que todos os realizadores do fato imponível do imposto, excepcionados os imunes ou beneficiários de isenção, deverão sujeitar-se à tributação.

Por fim, a progressividade consiste no aumento da alíquota do tributo à medida que há aumento da base de cálculo. Há o estabelecimento de alíquotas crescentes e progressivas em função do aumento da base de cálculo, isto é, a incidência aumenta em percentuais quando aumentam as riquezas que compõem a base de cálculo.

No caso do Imposto sobre a Renda, o critério da progressividade determina que, quanto maior for a base de cálculo do imposto, diga-se a renda líquida no caso da 
pessoa física e o lucro obtido no caso da pessoa jurídica, maior deverá ser alíquota aplicável para apuração do valor devido.

Desta forma, aquele possuidor de maiores rendimentos deve ser proporcionalmente mais tributado do que o possuidor em menor quantidade. Assim, o contribuinte que tem maiores rendimentos deve ser tributado de forma mais gravosa do que os detentores de montante inferior.

Os três critérios constituem corolário do princípio da isonomia ou igualdade tributária, previsto no artigo 150, inciso II, da Carta Magna, e também de modo reflexo do princípio da capacidade contributiva, consubstanciado no artigo $145, \S 1^{\circ}$, da Constituição Federal.

Infere-se, pois, que o Imposto sobre a Renda deve incidir de forma a satisfazer a generalidade, a universidade e progressividade, caraterísticas constitucionais da exação.

\section{Isenção tributária.}

O artigo 175 do Código Tributário Nacional estabelece que são causas de exclusão do crédito tributário a isenção e a anistia.

$\mathrm{Na}$ verdade, quando diante de umas das referidas causas, ainda que ocorrido o fato gerador do tributo e o consequentemente nascimento da obrigação tributária principal, não será possível a realização do lançamento tributário, não surgindo o crédito dele decorrente.

A diferença fundamental entre a isenção e a anistia é que a primeira exclui o crédito tributário relativo ao tributo, enquanto a segunda exclui o crédito tributário relativo a penalidade.

Ricardo Alexandre (2017, p. 572) conceitua isenção como sendo a dispensa legal do pagamento do tributo. Assim, o ente político tem competência para instituir o tributo e, ao fazê-lo, opta por dispensar o pagamento em determinadas situações.

No Código Tributário Nacional a isenção está regulada dos artigos 176 a 179, bem como estabelece o artigo 150, $\S 6^{\circ}$ da Constituição Federal, a necessidade de lei específica para sua concessão:

Qualquer subsídio ou isenção, redução de base de cálculo, concessão de crédito presumido, anistia ou remissão, relativos a impostos, taxas ou contribuições, só poderá ser concedido mediante lei específica, federal, 
estadual ou municipal, que regule exclusivamente as matérias acima enumeradas ou o correspondente tributo ou contribuição, sem prejuízo do disposto no Art. 155, § 2..$^{\circ}$, XII, g (grifo nosso)

A isenção se diferencia da imunidade tributária posto que, enquanto aquela é resultado de previsão numa lei específica, esta deriva de norma posta na Constituição Federal que estabelece uma incompetência tributária, já que os entes tributantes, ao instituírem tributos, não poderão fazer com que os mesmos incidam nas situações que foram imunizadas.

A imunidade é uma regra de não incidência, ao passo que na isenção há incidência com posterior dispensa do pagamento.

Leciona Vittorio Cassone que "[...] enquanto na imunidade não ocorre o fato gerador, porque a CF veda a tributação (veja ADI 939), na isenção o fato gerador ocorre (só pode haver isenção se há lei que tributa aquele fato), mas a lei dispensa seu pagamento" (2014, p. 127).

Desta feita, ao contrário da imunidade, a isenção é sempre concedida posteriormente ao exercício da competência tributária, diga-se, após a criação do tributo e somente pode derivar de lei do ente titular do poder de criar o tributo que a concede, a qual recebe o nome de isenção autônoma.

Em regra, não é possível a concessão de isenção por ente federado que não seja competente tributariamente; trata-se da vedação de concessão de isenções heterônomas, cuja proibição encontra respaldo no artigo 151, III, do Diploma Constitucional, e seu beneficiário estará obrigado ao cumprimento das obrigações tributárias acessórias, consistentes em obrigações de fazer ou não fazer, estabelecidas em prol da melhor arrecadação e fiscalização da exação.

No caso específico do Imposto sobre a Renda, o art. $6^{\circ}$ da Lei $n^{\circ} 7.713 / 1988$ (alterada por leis posteriores), em seus incisos, elenca as hipóteses de isenção do imposto para os rendimentos percebidos por pessoas físicas.

Desta forma, lei ordinária da União estabeleceu casos em que as pessoas naturais estarão dispensadas do pagamento do Imposto sobre a Renda sobre alguns de seus rendimentos, tais como alimentação, transporte e uniformes ou vestimentas especiais de trabalho, fornecidos gratuitamente pelo empregador a seus empregados etc.

Alguns projetos de lei tramitaram e tramitam no Congresso Nacional objetivando incluir dentre as hipóteses de isenção do Imposto sobre a Renda a 
remuneração percebida pelos professores. É o que versará o tópico subsequente e cuja inconstitucionalidade será demonstrada, não obstante a necessária valoração e proteção do trabalho como direito social, face afronta aos limites constitucionais ao poder de tributar, especialmente ao princípio da isonomia tributária.

\title{
3.1 Isenção de imposto sobre a renda na remuneração dos professores.
}

No ano de 2011, o Deputado Federal Felipe Bornier, do estado do Rio de Janeiro, apresentou o projeto de lei n. 2607 que propunha o acréscimo do inciso XXIII, no artigo $6^{\circ}$ da Lei $n^{\circ} 7.713 / 88$, com a seguinte redação:

XXIII - os valores recebidos da União, dos Estados, do Distrito Federal e dos Municípios, a título de remuneração, quando o beneficiário for professor lotado e em efetivo exercício na rede pública de educação infantil, fundamental, média e superior.

Ele justificou a presente inclusão no rol de isenções da lei do imposto sobre a renda por ser a educação um pilar para uma vida saudável e plena. Alegou ainda que por ser o Brasil carente de bons professores, tal isenção incentivaria a formação de novos profissionais e daria um novo ânimo aos novos, ingressarem na carreira do magistério.

Na justificativa do projeto, defende o deputado:

\begin{abstract}
Assim sendo, é oportuna a mudança que pretendemos efetuar. O magistério já é, por si mesmo, sacrificante, exigindo dedicação absoluta de quem o exerce. Justo que se dê a esse corpo profissional um tratamento condigno, como é merecido por uma classe de pessoas que são diretamente responsáveis pelo crescimento do Brasil.

Contamos, pois, com o apoio dos nobres Pares desta Casa para aprovação desta iniciativa, que pretende isentar do Imposto de Renda a remuneração de professores que exerçam na rede pública infantil, fundamental, média e superior as atividades de docente. (http://www.camara.gov.br/proposicoesWeb/prop mostrarintegra?codteor=9 $\underline{33764}$, p. 02)
\end{abstract}

Após a apresentação desse projeto de lei, outros com o mesmo propósito também foram apresentados na Câmara dos Deputados, e a este foram apensados. São eles:

a. Projeto de Lei $\mathrm{n}^{\circ}$ 6.167, de 2013, de autoria do Deputado Izalci, que concede isenção do imposto de renda para os rendimentos auferidos por professor no desempenho da atividade na esfera pública ou privada e independente do nível de ensino; 
b. Projeto de Lei $n^{\circ} 7.209$, de 2014, de autoria do Deputado Otávio Leite, que isenta do imposto de renda a remuneração auferida for professor em efetivo exercício de docência, coordenação, atividade pedagógica e/ou de pesquisa, na esfera pública e/ou privada, em todos os graus de ensino. Adicionalmente, o projeto atribui à União a obrigação de compensar os Estados e Municípios pelos efeitos financeiros decorrentes da medida, a ser realizada nos termos da Lei n. ${ }^{\circ} 11.494$, de 20 de junho de 2007, que instituiu o FUNDEB.

c. Projeto de Lei $\mathrm{n}^{\circ} 2.630$, de 2015, de autoria do Deputado Índio da Costa, que isenta da incidência do imposto de renda das pessoas físicas a remuneração dos professores.

Em reunião realizada no dia 17 de novembro de 2015, Comissão de Finanças e Tributação, examinou o Projeto de Lei $n^{\circ}$ 2.607, de 2011, em que o voto do relator, Deputado Edmilson Rodrigues, foi pela compatibilidade e adequação orçamentária e financeira do Projeto de Lei $n^{\circ} 2.607 / 2011$, dos Projetos de Lei $n^{\circ} 6.167 / 2013, n^{\circ}$ 7.209/2014, no 2.630/2015, apensados, com Substitutivo; e, no mérito, pela aprovação do Projeto de Lei no 2.607/2011 e dos Projetos de Lei no 6.167/2013, n ${ }^{\circ} 7.209 / 2014, n^{\circ}$ 2.630/2015, apensados, com Substitutivo.

No entanto, o projeto e seus apensos foram rejeitados pela maioria dos membros daquele colegiado, com os votos contrários dos deputados Joaquim Passarinho, Edmilson Rodrigues e Rodrigo Martins, tendo sido o Deputado Enio Verri designado como Relator do Vencedor.

Em 03 de dezembro de 2014 o assunto foi novamente levado a discussão, pela legalidade do projeto de lei, apensado ao principal, n. 7.209/14, do Deputado Federal Otávio Leite, também do estado do Rio de Janeiro, a qual foi considerada um afronto a um princípio constitucional tributário, qual seja, o da isonomia tributária. Sendo novamente rejeitada a proposta de lei que altera o texto legal sobre Imposto de Renda, acrescentado mais um inciso no seu art. $6^{\circ}$.

Outro projeto de lei, com texto similar, também tramita no Senado Federal, Projeto de Lei do Senado (PLS) $n^{\circ} 445$, de 2012, o qual prevê a inserção de um novo inciso no art. $6^{\circ}$ da Lei $\mathrm{n}^{\circ} 7.713 / 1988$, projeto este de autoria do Senador Sérgio Petecão, PSD/AC, que alega: 
O professor é o profissional cuja dedicação não tem como não ser exclusiva, ininterrupta. É um vocacionado no seu mister, sendo imune às intempéries. $\mathrm{O}$ ensino não está sujeito às contingências meramente econômicas, pois, a educação deve ser atividade em tempo contínuo, o que exige do profissional mais do que a vontade e o querer individual, mas é preciso que haja sobre magistério o reconhecimento de sua relevância pelo Estado e pela Sociedade. Além de beneficiar os professores em efetivo exercício, a ideia constante da proposta é incentivar o maior número possível de pessoas a migrarem para o exercício do magistério, pois, muitos profissionais se sentem desestimulados com a atividade de docência e acabam buscando outras atividades profissionais. (Justificativa do PLS 445/2012 (www.senado.leg.br/atividade/rotinas/materia/getDocumento.asp?t=119527)

Referido projeto foi a votação na Comissão de Educação, Cultura e Esporte que o rejeitou por ferir o princípio constitucional da isonomia tributária. A Senadora Maria do Carmo Alves, relatora do parecer, em 11 de novembro de 2014, além da inconstitucionalidade, defendeu que a medida causaria um forte impacto na educação brasileira, já que a faixa de profissionais que seriam contemplados por tal isenção não seria a sua totalidade.

Com efeito, não é demais dizer que os professores brasileiros com jornada de 40 horas semanais, em grande maioria, não seriam beneficiados pela medida. A exceção ficaria com parcela ínfima formada por docentes com vínculo com a União, ou que, de outras esferas administrativas, exercem magistério na educação superior.

Por essa razão, entendemos que a proposição não é oportuna. Parece-nos essencial, primeiro, a exemplo do que propõe o Plano Nacional de Educação ora em discussão no Congresso Nacional, garantir aos professores das mais de 150 mil escolas estaduais e municipais níveis de remuneração condignos, o que os aproximará da condição de contribuintes na legislação do IRPF. A nosso juízo, não faz sentido garantir um direito em face de um dever que não tem fundamento fático. Em outras palavras, não adianta assegurar a isenção a quem não atingiu a condição de contribuinte. $\mathrm{Na}$ verdade, estaríamos satisfeita se todos os professores brasileiros já tivessem logrado esse patamar salarial.

(file:///C:/Users/suhel/Downloads/DOC-Relat\%C3\%B3rio\%20Legislativo20140319.pdf, p. 04)

O Projeto de Lei do Senado (PLS) n 445, de 2012, de autoria do Senador Sérgio Petecão, ainda tramita no Senado Federal e, atualmente, encontra-se na Comissão de Assuntos Econômicos para parecer e votação.

\section{0 princípio da isonomia tributária.}

Estabelece o Texto Constitucional, em seu art. $5^{\circ}$, caput, que todos são iguais perante a lei, não sendo permitida distinção de qualquer natureza, garantindo-se aos 
brasileiros e estrangeiros a inviolabilidade do direito à vida, à igualdade, à segurança e à propriedade.

De acordo com a definição de Humberto Ávila (2006, p. 137):

A igualdade pode funcionar como regra, prevendo a proibição de tratamento discriminatório; como princípio, instituindo um estado igualitário com o fim a ser promovido; e como postulado, estruturando a aplicação do Direito em função de elementos (critérios de diferenciação e finalidade da distinção) e da relação entre eles (congruência do critério em razão do fim).

Derivado do princípio geral previsto no art. $5^{\circ}$, em matéria tributária, o princípio vem expresso dentre as limitações ao poder de tributar, especificamente no art. 150, inciso II, da Carta Magna:

Art. 150. Sem prejuízo de outras garantias asseguradas ao contribuinte, é vedado à União, aos Estados, ao Distrito Federal e aos Municípios: [...] II - instituir tratamento desigual entre contribuintes que se encontrem em situação equivalente, proibida qualquer distinção em razão de ocupação profissional ou função por eles exercida, independentemente da denominação jurídica dos rendimentos, títulos ou direitos; [...]

O princípio da igualdade tributária expressa que todos os contribuintes que estiverem numa mesma situação devem ter o mesmo tratamento tributário, ao passo que os contribuintes em situações diferentes devem ter tratamento diferenciado, sob pena de inconstitucionalidade.

O tratamento isonômico é uma regra que deve ser observada pelo legislador ao exercer a competência tributária, bem como pelo aplicador do direito ao fazer seu trabalho hermenêutico.

A igualdade fiscal, de acordo com Victor Uckmar (1999, p. 67), pode ser entendida também em dois sentidos:

a) em sentido jurídico, como paridade de posição, com exclusão de qualquer privilégio de classe, religião e raça, de modo que os contribuintes que se encontrem em idênticas situações sejam submetidos a idêntico regime fiscal; b) em sentido econômico, como dever de contribuir aos encargos públicos em igual medida, entendida em termos de sacrifício, isto é, [...] em relação à capacidade contributiva dos indivíduos.

Segundo Eduardo Sabbag (2016, p. 140) o princípio da igualdade tributária:

[...] é também conhecido por "princípio da proibição dos privilégios odiosos", na medida em que visa coibir a odiosidade tributária, manifestável em comandos normativos discriminatórios, veiculadores de favoritismos por meio da tributação.

A capacidade contributiva das pessoas tem sido um dos principais parâmetros a ser levado em consideração para a imputação de algum tipo de tratamento diferenciado, 
em matéria de tributação. Pode-se, portanto, alegar que o princípio da capacidade contributiva está umbilicalmente ligado ao da isonomia, dele decorrendo diretamente.

Inocêncio Mártires Coelho (2009, p. 1397) esclarece:

[...] impõe-se ter presente que a igualdade aqui exigida, como de resto a igualdade em geral, não proíbe, antes exige, que o legislador, como o juiz, tenha presentes as desigualdades reais, discriminando onde, quando e em relação a quem se deve discriminar - obviamente de modo razoável e fundamentado -, a fim de alcançar a igualdade real, que outra coisa não significa senão tratar igualmente os iguais e desigualmente os desiguais, na medida de sua desigualdade. Neste sentido, impõe-se convocar, desde logo, a incidência de outro princípio da ordem constitucional tributária - o da capacidade contributiva -, de modo a realizar a justiça em sentido material, cobrando de cada um aquilo que, efetivamente, ele pode pagar, ou até mesmo dispensando-o do pagamento de tributos, por meio de isenções, nos termos e condições estabelecidos em lei.

Outrossim, não se pode olvidar a ligação do princípio da igualdade com a justiça fiscal. Por meio da igualdade busca-se a aplicação da justiça, na medida em que a igualdade se realiza mediante a aferição da real capacidade contributiva, a fim de adequar a tributação à realidade social e a atender às necessidades dos cidadãos.

Todavia, a vedação contida no princípio da isonomia tributária de instituição de tratamento desigual entre contribuintes que se encontrem em situação equivalente, não permite que seja estabelecida qualquer distinção entre os sujeitos passivos do tributo tendo por base a ocupação profissional ou função por eles exercida, é o que restará demonstrado.

\subsection{Violação do princípio da isonomia tributária em razão da isenção de Imposto sobre a Renda (IR) na remuneração dos professores.}

Em pese a concretização da dignidade da pessoa humana exigir a valoração e proteção do trabalho e dos direitos dos trabalhadores, seja como direito fundamental, seja como direito social, referido resguardo não permite a concessão por lei da União de isenção de Imposto sobre a Renda na remuneração percebida pelos professores face a afronta ao princípio da isonomia tributária.

Ofende o princípio da igualdade ou isonomia tributária o estabelecimento de diferenciação tributária, no caso específico um benefício fiscal, levando-se em consideração, única e exclusivamente, a ocupação profissional ou a função exercida por uma categoria profissional, qual seja a dos professores. 
Conforme restou demonstrado, tramitaram e ainda tramitam no Congresso Nacional projetos de leis ordinárias objetivando alterar o art. $6^{\circ}$ da Lei $\mathrm{n}^{\circ} 7.713 / 1988$, de forma a incluir, dentre as hipóteses de rendimentos percebidos por pessoas físicas não sujeitos à incidência do Imposto sobre a Renda, a remuneração auferida pelos professores.

É sabido que a classe profissional dos professores não é valorizada o quanto deveria e que a remuneração recebida, na maioria das vezes, é irrisória fazendo com que os profissionais tenham jornada tripla de trabalho para conseguir ter uma vida digna.

Também é indiscutível a importância do exercício da atividade profissional dos professores na formação dos cidadãos, sendo considerada uma das atividades mais nobres das exercidas e de forte impacto social. A educação, muito embora seja o sustentáculo de uma vida plena, carece atualmente de educadores em razão das grandes dificuldades encontradas no exercício efetivo do trabalho por estes profissionais.

Outrossim, é preciso que haja o reconhecimento da relevância pelo Estado e pela Sociedade da atividade do magistério adotando-se políticas afirmativas objetivando a efetivação da proteção e da garantia ao direito social ao trabalho e aos direitos dos trabalhadores.

Assim, indiscutível é a obrigação do poder público de criar mecanismos que incentivem o ingresso e o exercício do magistério, todavia, estes estímulos não poderão ocorrer via concessão de isenção do Imposto sobre a Renda na remuneração recebida pelos professores. Isto porque, o exercício de uma profissão ou atividade profissional não pode ser o critério eleito pela legislação para o estabelecimento de benefícios fiscais e, assim, dispensar o pagamento de tributo.

O princípio da isonomia tributária ou igualdade tributária, consubstanciado no art. 150, inciso II, da Constituição Federal, veda a instituição de tratamento desigual entre contribuintes que se encontrem em situação equivalente e proíbe qualquer distinção em razão de ocupação profissional ou função por eles exercida, independentemente da denominação jurídica dos rendimentos, títulos ou direitos.

Desta forma, não é permitido tratamento desigual entre pessoas físicas em função de suas atividades laborais se a capacidade contributiva delas é a mesma. Quando se distingue uma pessoa física da outra pela posição ocupada ou atividade exercida ocorre a violação do princípio constitucional tributário da isonomia. 
Duas pessoas que auferem a mesma renda em trabalhos distintos, uma é professora e a outra fisioterapeuta, não podem ser tributadas de forma diferente pelo IR, única exclusivamente, porque uma exerce o magistério e a outra não.

Sobre tal tema, Ricardo Alexandre (2017, p. 145) disserta:

A proibição tenta acabar com a situação anterior à Constituição Federal de 1988, quando algumas classes de pessoas conseguiam aprovar leis que, mudando a denominação jurídica das respectivas remunerações (normalmente denominando boa parte dos rendimentos de "ajuda de custo"), conseguiam diminuir consideravelmente a carga tributária a que estariam sujeitas em condições normais.

Justamente por isso, a Constituição Federal de 1988 completou a proibição de tratamento diferenciado com base em ocupação ou cargo com a cláusula "independentemente da denominação jurídica dos rendimentos, títulos ou direitos".

Percebe-se que ao tentar isentar os professores do pagamento do Imposto sobre a Renda ocorre uma violação expressa aos preceitos do art. 150, inciso II, do texto constitucional, que veda justamente a concessão de isenção de tributos levando em consideração o cargo ocupado ou a função exercida pela pessoa física.

Sacha Calmon Navarro Coelho (2007, p. 275) demonstra a vedação contida no dispositivo em comento tratando especificamente do Imposto sobre a Rrenda:

Quer nos parecer, no entanto, que o dispositivo refulge com maior brilho para o imposto de renda. A própria redação do artigo trai a direção desse clarão. Ao falar em proibição de tratamento desigual entre contribuintes que se encontram em situação equivalente, veda qualquer distinção em razão da ocupação profissional ou função por eles exercidas, independentemente da denominação jurídica dos rendimentos, títulos ou direitos - a conjectura é do comentarista - esteve o constituinte a pensar nos lucros bursáteis, nos militares, nos legisladores, nos juízes, nos fazendeiros, nas sociedades de profissionais liberais e outros, desenganadamente beneficiados pela não incidência de IR ou incidência mitigada deste sobre seus ganhos.

Qualquer projeto de lei federal que tente conceder isenção para os rendimentos de uma determinada categoria profissional estará eivado de inconstitucionalidade, já que o exercício de uma atividade não pode ser usado como elemento de diferenciação tributária.

Ademais, no caso específico do Imposto sobre a Renda, como exposto, deve a incidência tributária observar o critério da generalidade, ou seja, o imposto deve atingir todas as pessoas que auferem renda e proventos, sem distinção.

Eventuais isenções de imposto sobre a renda não podem levar em consideração apenas a função exercida já que ela não demonstra a capacidade contributiva do sujeito passivo. No caso em análise, alguém que receba a mesma remuneração que um dado 
professor não terá direito à isenção, de forma que, o trabalho desenvolvido não é apto a demonstrar a capacidade contributiva de alguém. Assim, não é possível concluir que o profissional tem maior capacidade contributiva que o professor e, por isso, deve contribuir aos cofres públicos.

Explica Roque Antonio Carrazza (2006, p. 66):

Eventuais isenções somente são admitidas quando rendem homenagens ao princípio da igualdade e, por extensão, ao da capacidade contributiva. Melhor explicando, elas somente podem ser concedidas quando levam em conta objetivos constitucionalmente consagrados (proteção à velhice, à família, à cultura, aos deficientes mentais, aos doentes incuráveis, aos economicamente mais fracos - isto é, que revelam incapacidade econômica para suportar o encargo sem se privarem do mínimo vital - e, assim por diante).

Em suma, não obstante a proteção constitucional do direito ao trabalho e aos direitos dos trabalhadores, gozam de inconstitucionalidade todos os projetos de leis ordinárias que objetivem incluir dentre as hipóteses de isenção de Imposto sobre a Renda a remuneração auferida pelos professores por afrontar o princípio da isonomia tributária, consubstanciado no art. 150, inciso II, da Constituição Federal, bem como por violar o critério da generalidade, caraterística informadora do imposto federal.

\section{CONCLUSÃO}

A concretização da dignidade da pessoa humana exige a valoração e proteção do trabalho e dos direitos dos trabalhadores, seja como direito fundamental, seja como direito social, conforme impõe o artigo $6^{\circ}$ da Constituição Federal e demais normas protetivas da relação de emprego.

Em sendo assim, necessário é a tomada de medidas por parte do Poder Público que objetivem não só proteger os direitos do trabalhador, como também o seu direito ao trabalho.

É neste contexto que pretende o Poder Legislativo Federal a aprovação de lei que conceda isenção de Imposto sobre a Renda sobre a remuneração auferida por uma classe específica de trabalhadores, qual seja, a categoria dos professores.

O Imposto sobre a Renda é um imposto da competência da União que tem como fato gerador a obtenção de acréscimos patrimoniais, ou seja, a exação incide sobre o saldo positivo aferido pelo contribuinte ao final de um dado período de tempo. 
É causa de exclusão do crédito tributário a concessão de isenção, que consiste na dispensa legal do pagamento de um determinado tributo por parte do ente tributariamente competente.

No caso específico do Imposto sobre a Renda, conforme restou demostrado, o art. $6^{\circ}$ da Lei $\mathrm{n}^{\circ} 7.713 / 1988$ (alterada por leis posteriores), em seus incisos, elenca hipóteses de isenção do imposto para os rendimentos percebidos por pessoas físicas.

Desta forma, lei ordinária da União estabeleceu casos em que as pessoas naturais estarão dispensadas do pagamento do Imposto sobre a Renda sobre alguns de seus rendimentos, tais como alimentação, transporte e uniformes ou vestimentas especiais de trabalho, fornecidos gratuitamente pelo empregador a seus empregados etc.

Tramitaram e tramitam no Congresso Nacional projetos de leis objetivando incluir, dentre as hipóteses de isenção do Imposto sobre a Renda, a remuneração percebida pelos professores.

Em pese, por um lado, a importância da atividade docente e o papel social dos professores na formação dos cidadãos, bem como a dificuldade encontrada por eles no exercício da atividade docente e, de outro lado, a necessidade da realização por parte do Estado de medidas afirmativas objetivando proteger o trabalho enquanto direito social, é inconstitucional, face a afronta ao princípio da isonomia tributária, qualquer projeto de lei que objetive a concessão de isenção de Imposto sobre a Renda na remuneração auferida por qualquer categoria profissional, no caso analisado, a dos professores.

O princípio da isonomia tributária, previsto no artigo 150, inciso II, da Constituição Federal, veda a instituição de tratamento desigual entre contribuintes que estejam em situação equivalente e proíbe qualquer distinção em razão de ocupação profissional ou função por eles exercida.

Não podem os professores, pelo simples fato de integrarem uma categoria profissional específica, terem direito ao não pagamento do Imposto sobre a Renda. Não é isonômico que duas pessoas que tenham a mesma renda, ou seja, possuam a mesma capacidade contributiva, sejam tratadas de forma distinta, única e exclusivamente, porque uma pertence a classe dos professores e a outra não.

Além de afrontar o princípio da isonomia tributária, a inconstitucionalidade da pretendida isenção é corroborada pela inobservância de um dos três critérios informadores do Imposto sobre a Renda: o da generalidade. 
O critério da generalidade, previsto no artigo art. 153, $\S 2^{\circ}$, inciso I, da Constituição Federal, impõe que a incidência do imposto alcance todas as pessoas que realizarem o fato gerador, isto é, todo aquele que auferir "renda e proventos de qualquer natureza”. Assim, impõe que qualquer pessoa que obtiver riqueza nova no período necessário para sua verificação deva sofrer a incidência da exação.

Desta forma, restou cristalino no trabalho, que decorre do cumprimento ao critério da generalidade a vedação do estabelecimento de privilégios e discriminações entre contribuintes, já que a determinação constitucional tem por escopo impedir desigualdades, evitando discriminações tributárias face as características pessoais do contribuinte ou de suas condições.

Em suma, todo e qualquer projeto que objetive a concessão de isenção de Imposto de Renda sobre a renda de uma determinada categoria profissional goza de inconstitucionalidade por violação ao princípio da isonomia tributária e ao critério da generalidade. São, portanto, inconstitucionais os projetos de leis que tramitam no Congresso Nacional com fulcro a isentar os professores da incidência do Imposto sobre a Renda.

\section{REFERÊNCIAS}

ALEXANDRE, Ricardo. Direito tributário esquematizado, 11 ed. Salvador: JusPodivm, 2017.

ALVES, Maria do Carmo. Parecer $\mathrm{n}^{\mathrm{o}}$, de 2014. Disponível em: file:///C:/Users/suhe1/Downloads/DOC-Relat\%C3\%B3rio\%20Legislativo20140319.pdf. Acesso em 12 maio 2017.

ARAÚJO, Luiz Alberto David; NUNES JÚNIOR, Vidal Serrano. Curso de direito constitucional. 14 ed. São Paulo: Saraiva, 2010.

ÁVILA, Humberto. Teoria dos princípios. 6. ed. São Paulo: Malheiros, 2006.

BORNIER, Felipe. Projeto de Lei n. , de 2011. Disponível em: http://www.camara.gov.br/proposicoesWeb/prop_mostrarintegra?codteor=933764.

Acesso em: 16 abr. 2017.

CARRAZZA, Roque Antonio. Imposto sobre a renda: perfil constitucional e temas específicos. 2.ed. rev., ampl. e atual. São Paulo: Malheiros, 2006.

CASSONE, Vittorio. Direito tributário. 24 ed. São Paulo: Atlas, 2014.

COÊLHO, Sacha Calmon Navarro. Curso de direito tributário brasileiro. 9.ed. rev. e atual. de acordo com o Código Civil de 2002. Rio de Janeiro: Forense, 2007.

DELGADO, Mauricio Godinho. Curso de direito do trabalho. São Paulo: LTr, 2005. 
GRAU, Eros Roberto. A ordem econômica na Constituição de 1988. (interpretação e crítica). 16 ed. São Paulo: Malheiros, 2014.

GONÇALVES, José Artur Lima. Imposto sobre a renda: pressupostos constitucionais. São Paulo: Malheiros, 2002.

LEDUR, José Felipe. A realização do direito ao trabalho. Porto Alegre: Sérgio Antônio Fabris Editor, 1998.

LENZA, Pedro. Direito constitucional esquematizado. São Paulo: Saraiva, 2010.

MENDES, Gilmar Ferreira; COELHO, Inocêncio Mártires; BRANCO. Paulo Gustavo Gonet. Curso de direito constitucional. 4 ed. São Paulo: Saraiva, 2009.

NOVELINO, Marcelo. Direito Constitucional. São Paulo: Método, 2012.

NUNES JUNIOR, Flávio Martins Alves. Curso de direito constitucional. 1 ed. São Paulo: Revista dos tribunais, 2017.

MORAES, Alexandre de. Direito constitucional. 12 ed. São Paulo: Atlas, 2002.

QUEIROZ, Mary Elbe. Imposto sobre a renda e proventos de qualquer natureza. Rio de Janeiro: Manole, 2004.

SABBAG, Eduardo. Manual de direito tributário. 8. ed. São Paulo: Saraiva, 2016.

Silva, José Afonso da. Curso de Direito Constitucional Positivo. São Paulo: Editora Malheiros.

PETECÃO, Sérgio. Projeto de lei do Senado $\mathrm{n}^{\circ}$, de 2012. Disponível em www.senado.leg.br/atividade/rotinas/materia/getDocumento.asp?t=119527. Acesso em: 12 maio 2017.

UCKMAR, Victor. Princípios comuns de direito constitucional tributário. Tradução e notas de Marco Aurélio Greco. 2.ed. rev. e atual. São Paulo: Malheiros, 1999. 